\title{
Standardization of the duty shift in a General Adult Intensive Care Unit
}

\author{
Padronização da passagem de plantão em Unidade de Terapia Intensiva Geral Adulto \\ Estandarización del paso de turno en Unidad de Terapia Intensiva General Adulto
}

\section{Roselene Campos Corpolato' ORCID: 0000-0002-1715-9910}

Maria de Fátima Mantovani' ORCID: 0000-0001-7961-8273

Mariluci Hautsch Willig' ORCID: 0000-0003-0170-335X

Luciana Aparecida Soares de Andrade' ORCID: 0000-0002-8712-510X

\section{Ângela Taís Mattei' ORCID: 0000-0002-4927-3806}

Juliana Perez Arthur' ORCID: 0000-0002-1465-0202

'Universidade Federal do Paraná. Curitiba, Paraná, Brazil.

How to cite this article: Corpolato RC, Mantovani MF, Willig MH, Andrade LAS, Mattei AT, Arthur JP. Standardization of the duty shift in a General Adult Intensive Care Unit. Rev Bras Enferm [Internet]. 2019;72(Suppl 1):88-95.

[Thematic Issue: Work and Management in Nursing]. DOI: http://dx.doi.org/ 10.1590/0034-7167-2017-0745

Corresponding Author: Roselene Campos Corpolato E-mail: r.corpolato@hotmail.com

Submission: 09-18-2017

Approval: 03-14-2018

\begin{abstract}
Objective: To standardize the duty shift in a General Adult Intensive Care Unit. Method: Multi-method research, which used action research, descriptive study and content validation. Participants included 11 care nurses and 4 intensive care nurses. For the data collection, a semi-structured questionnaire was used, meetings with participants and validation with specialists. In this step, the modified online Delphi Technique was used. For data treatment, the Discourse of the Collective Subject (DCS) was used, descriptive analysis and Content Validity Index. Results: Three DCS on duty change, a Standard Operating Procedure (SOP) and an information registration instrument, validated in appearance, clarity, suitability and content. Final considerations: The instrument assists in the transmission of information, strengthening patient safety and SOP will outline the shift, these tools can improve ICU shift, minimizing the risks of communication failure.

Descriptors: Communication; Critical Care; Nursing care; Shift Work; Patient Safety.
\end{abstract}

\section{RESUMO}

Objetivo: Padronizar a passagem de plantão em uma Unidade de Terapia Intensiva Geral Adulto. Método: Pesquisa multimétodo, que utilizou a pesquisa-ação, o estudo descritivo e a validação de conteúdo. Os participantes foram 11 enfermeiros assistenciais e quatro enfermeiros especialistas em cuidados intensivos. Para a coleta de dados foi aplicado um questionário semiestruturado, reuniões com participante e validação com especialistas. Nesta etapa, utilizou-se a Técnica Delphi online modificada. Para tratamento dos dados, empregou-se o Discurso do Sujeito Coletivo (DSC), análise descritiva e Índice de Validade de Conteúdo. Resultados: Três DSC sobre passagem de plantão, um Procedimento Operacional Padrão (POP) e um instrumento de registro de informações, validado em aparência, clareza, adequabilidade e conteúdo. Considerações finais: $\mathrm{O}$ instrumento auxilia na transmissão de informações, fortalecendo a segurança do paciente e o POP vai delinear a passagem de plantão, essas ferramentas podem melhorar a passagem de plantão da UTI, minimizando os riscos de falhas de comunicação.

Descritores: Comunicação; Cuidados Críticos; Cuidados de Enfermagem; Trabalho em Turnos; Segurança do Paciente.

\section{RESUMEN}

Objetivo: Padronizar el paso de turno en una Unidad de Terapia Intensiva General Adulto. Método: Investigación multiuso, que utilizó la investigación-acción, el estudio descriptivo y la validación de contenido. Los participantes fueron 11 enfermeros asistenciales y cuatro enfermeros especialistas en cuidados intensivos. Para la recolección de datos se aplicó un cuestionario semiestructurado, reuniones con participante y validación con especialistas. En esta etapa, se utilizó la Técnica Delphi online modificada. Para el tratamiento de los datos, se empleó el Discurso del Sujeto Colectivo (DSC), análisis descriptivo e Índice de Validez de Contenido. Resultados: Tres DSC sobre pasaje de turno, un Procedimiento Operativo Estándar (POP) y un instrumento de registro de informaciones, validado en apariencia, claridad, adecuación y contenido. Consideraciónes finales: El instrumento auxilia en la transmisión de informaciones, fortaleciendo la seguridad del paciente y el POP va delineando el paso de turno, esas herramientas pueden mejorar el paso de turno de la UTI, minimizando los riesgos de fallas de comunicación.

Descriptores: Comunicación; Cuidados Críticos; Cuidados de Enfermería; Horario de Trabajo por Turnos; Seguridad del Paciente. 


\section{INTRODUCTION}

Communication is a valuable tool in the health area, it is a light technology essential in the recognition and effectiveness of the professional and the user as protagonists in health coproduction $^{(1)}$. Given the importance of effective communication among health professionals, the World Health Organization (WHO) has defined the goal of improving communication during shift procedures and patient transfers ${ }^{(2)}$.

WHO, in partnership with The Joint Commission (TJC), has also established guidelines for meeting this goal: limiting interruptions, using clear language, conducting interactive communication among stakeholders, avoiding the use of internationally nonstandard abbreviations, the possibility of using technologies and information record in tools standardized by institutions ${ }^{(2-3)}$.

In nursing care, it is essential to adopt an adequate flow for the communication processes, both for care and administrative activities ${ }^{(4)}$. Among the communication processes, it is worth mentioning the duty shift, which has the primary function of transmitting information, since it is possible to plan the actions of the subsequent shift and ensure the continuity of the assistance $^{(4-5)}$.

Duty shift is a communication channel between shifts ${ }^{(6)}$. It occurs in different forms or modalities, the most common being verbal reports, written reports, bedside reports or team meetings, which may occur in isolation or associated ${ }^{(7)}$. The verbal reports together with the written report are presented as one of the most used forms, since it reduces the omission of relevant questions and that can be forgotten if only verbal communication were used $^{(7)}$.

In order to guarantee an effective communication process during duty shift, it is important that standardized protocols are implemented, especially in critical units such as Intensive Care Units (ICU), since protocols allow fundamental principles to be respected and adverse events associated with lack be reduced in order to guarantee the quality, continuity of care and patient safety ${ }^{(8)}$.

The Intensive Care Unit (ICU) is a critical area of the hospital, where serious or at-risk patients with potential for recovery are seen. The assistance is uninterrupted and carried out by a specialized multidisciplinary team ${ }^{(9)}$.

The nurse is part of the multidisciplinary team and has a high demand for highly complex tasks and activities, thus requiring continuous improvement and aptitude to develop the nursing process, formulate specific plans, make effective prescriptions and assess health status through nursing assessments ${ }^{(10)}$.

In addition to these activities, the intensive care nurse performs management actions, including the elaboration of protocols, nursing routines, administration of technological resources and materials, educational activities, articulation with the multiprofessional team and interlocution with other sectors of the hospital, so this professional develop means to facilitate communicative processes ${ }^{(11)}$.

\section{OBJECTIVE}

This study aims to standardize the nursing duty shift in a General Adult ICU.

\section{METHOD}

\section{Ethical aspects}

The project was approved by the Ethics Committee in Research on Human Beings and had the formal consent of the participating institution for the collection of data.

\section{Theoretical-methodological framework}

The study is based on the methodology of action research. This type of research is developed through an action or resolution of a collective problem in which researchers and participants representing the situation or problem are involved in a cooperative or participatory manner ${ }^{(12)}$.

The action research consists of the following phases: field of observation, sampling and qualitative representativeness, action plan, exploratory, data collection, research theme, problem placement, theory place, hypotheses, seminars, learning, formal and informal, and external dissemination ${ }^{(12)}$. Unlike other researches, in which the phases follow a strictly ordered series, in action research they proceed in a flexible and dynamic way, do not have to be linear, can occur simultaneously and do not obey a given time sequence ${ }^{(12)}$.

\section{Type of study}

This is a multi-method study, which used action research for the qualitative part, and descriptive study and content validation for the quantitative part.

\section{Methodological procedures: place, participants, data col- lection and analysis}

The research was carried out in a General Adult ICU with 20 beds, located in a reference hospital in trauma care located in the city of Curitiba, Paraná State.

Due to the choice of the participants, qualitative representativeness was used, they are a small group of people who are chosen intentionally according to the relevance that they present in relation to a certain subject, this principle is systematically used in action research ${ }^{(12)}$. The participants were the nursing assistants who worked at the research site, the eligibility criteria consisted of: being a nurse, working in the sector for more than three months and not being on vacation or working leave during the data collection period, which occurred in three phases in the period from April 2016 to June 2017.

The data collection took place in three moments, first in the exploratory phase, which consists of discovering the field of research, the interested ones and their expectations, and to establish a first survey or diagnosis of the situation and the priority problems. This phase is marked by the need to identify the information that is relevant to the construction of the project, elaboration of the objectives and the way in which the participants will act ${ }^{(12)}$.

At the moment, a semistructured questionnaire was elaborated, elaborated by the researcher, containing six questions, which refer to aspects such as: the importance of duty shift for nursing care, patient information to be addressed, organizational items of the unit, modalities, time spent, and interferences during the activity. 
The second moment occurred during the seminars, which consisted of meetings with the participants, which were divided into five groups, and a meeting was held with each group, totaling five meetings. During the meetings, an expositive lecture was given whose content covered concepts related to duty shift, the data acquired with the questionnaire was also presented and a tool for recording patient information for duty shift use (version 1) was drawn from the data obtained by the questionnaire.

In the sequence, discussions began to standardize the duty shift in the unit, evaluating and adapting the instrument, giving rise to version 2 and capturing content to formulate a Standard Operational Procedure (SOP) to delineate the activity. The predilection for the SOP occurred as a consequence of this being the form of standardization of the nursing procedures in the study institution. The content of the meetings was recorded through audio recordings and were subsequently transcribed.
For the treatment of the data of these phases, the technique of the Discourse of the Collective Subject (DCS) was used. This technique consists of a speech-synthesis written in the first person singular, composed of methodological figures represented by Key Expressions (KE) that have the same Central Idea (CI) and/or Anchorage (AC). Open questions are tabulated from the reading of the answers and the identification of a word, or concept, or expression that reveals the essence of the meaning of the response ${ }^{(13)}$. To ensure the confidentiality of participants, they were identified in the speeches by the letter "E" followed by numbers from one to 11, respectively, according to the number of participants in this phase. In the questions of multiple alternatives of the questionnaire and for the content obtained in the meetings, the descriptive analysis was used.

Although the action-research phases were not linear, a flow chart was elaborated, presented in Figure 1, in order to facilitate the visualization of the actions performed in each phase.

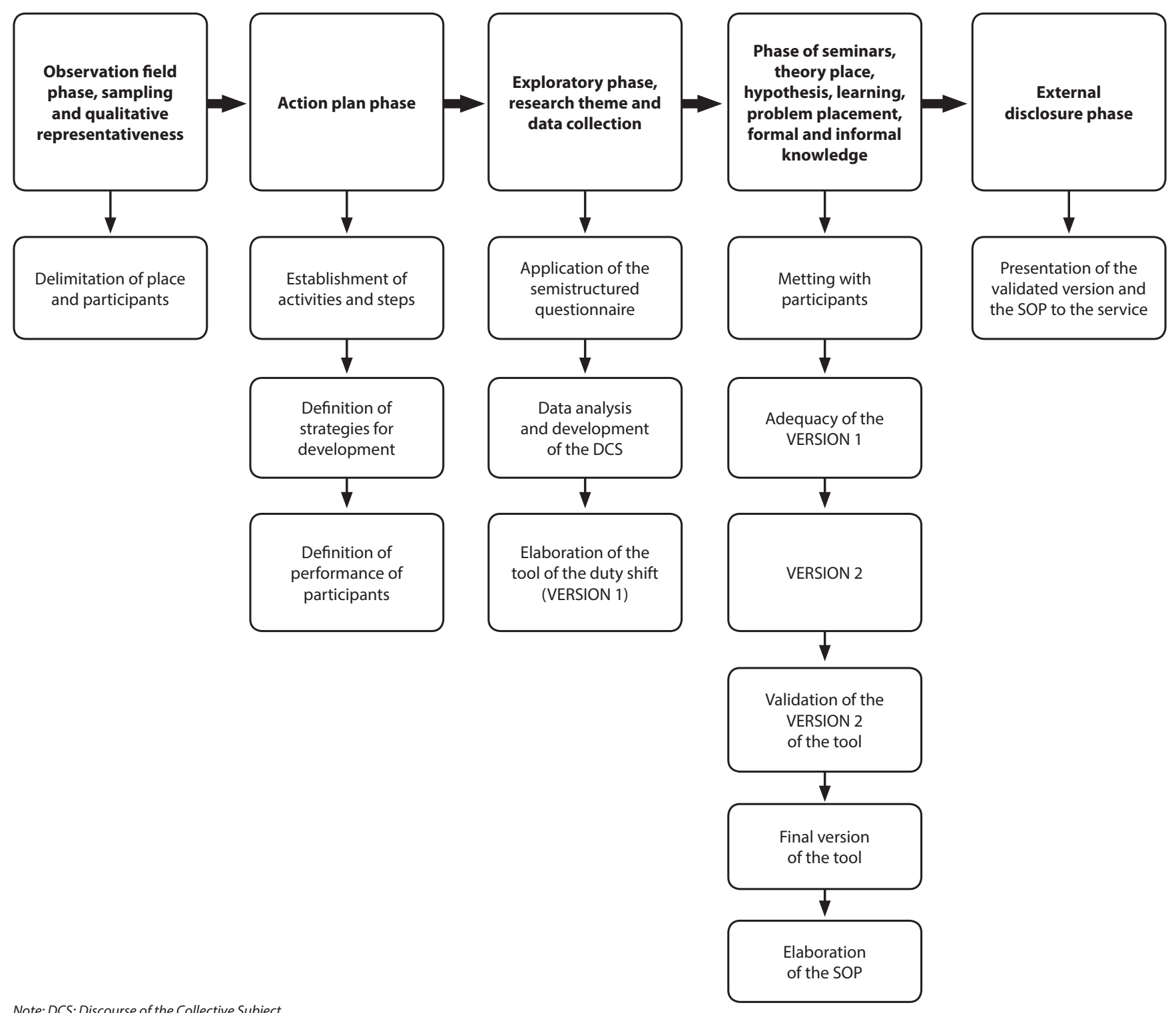


The third moment of the data collection was the validation of version 2 of the registry instrument, this phase occurred through the Delphi Technique. This is characterized as a method used to obtain reliable consensus of opinion by a group of experts to a series of questionnaires with controlled feedback ${ }^{(14)}$.

We chose the modified online Delphi technique using the Google Forms ${ }^{\circledast}$ platform, which is part of a free toolkit offered by Google ${ }^{\circledast}$. An online form was elaborated that included a brief summary of the research, the Informed Consent Term, for the participants who accepted to participate in the validation, a segment for the characterization of the participants and another segment for the evaluation process of the instrument. duty shift, in relation to appearance, clarity, suitability to the target sector, and the items that constituted the instrument. A Likert scale was applied to evaluate the content of the instrument, on a scale of 1 to 4, with 1 representing that the researcher considered the item not suitable, and 4 that he considered the most appropriate item.

Content Validity Index (CVI) was used to analyze data in content validation. This method measures the proportion or percentage of judges who are in agreement on certain aspects of the instrument and its items, initially provides the analysis of each item individually and then the instrument as a whole. The score of the index is calculated by means of the sum of agreement of the items that were marked by " 3 " or " 4 " by the experts, in the Likert scale. Items that have scored "1" or "2" should be reviewed or deleted. In order to evaluate the instrument as a whole, all the calculated CVI were added separately and were divided by the number of items considered adequate in the evaluation ${ }^{(15)}$.

\section{RESULTS}

Of the 11 assistant nurses participating, seven were female and four male, with an average age of 35 years and average training time in the 11-year area. In relation to the higher degree, one of the participants had masters, six specializations and four graduations.

In the exploratory phase, from the questionnaire question: "In your opinion, what is the importance of the duty shift for the nursing care?", Three Central Ideas $(\mathrm{Cl})$ have emerged: being $\mathrm{Cl}$ "A": A duty shift as a guarantee of continuity of care; $C l$ " $B$ ": A duty shift as a means for the planning of nursing care; $\mathrm{Cl}^{\prime \prime} \mathrm{C}$ ": The duty shift as a tool for the organization of work. These central ideas, in turn, generated three Discourses of the Collective Subject - DCS.

\section{Central Ideas "A": Duty shift as a guarantee of continuity of assistance}

DCS:

I understand that the duty shift allows the continuity of care, from it I have more assertive attitudes, since I recognize what behaviors must be taken in order to ensure the continuity of the direct and indirect care provided to the patient. (E4, E5, E7, E8)

\section{Central Ideas "B": Duty shift as means for nursing care planning}

DCS:
The duty shift guides my conduct, from there I plan the activities and determine the priority in performing the patient's procedures. I think it consists of the exchange of vital information. The wellbeing of the patient during the period served, changes in diets, medication and discharge, for this the duty shift must be complete and compromised, so I can plan and elaborate an adequate plan of care. (E1, E2, E3, E5, E6, E9, E11)

\section{Central Ideas "C": Duty shift as a tool for the organization of work}

DCS:

I believe that duty shift is of fundamental importance for a better organization of work. From the exchange of information among teams, on the evolution of the patient, what has been done and what will be accomplished, it can proceed in an organized and systematic way in the care process. In this way, I can reduce possible flaws in the planning of routines established daily, regarding patient care, technical and organizational issues of the ICU. (E6, E7, E10)

Regarding the questions of multiple alternatives that refer to patients'information, which should be reported in the duty shift, all participants $(n=11)$ indicated: identification, level of consciousness, invasive monitoring, use of vasoactive drugs, type ventilation, presence of drains, performed exams, appointments, skin lesions and eliminations. The use of sedatives was indicated by ten nurses, the use of antibiotics by eight, catheters and devices was indicated by five of the nurses. These data formed the basis for the preparation of version 1 of the registration tool, which was structured in the format of a checklist, the size of a full page.

Regarding the organizational items of the unit that should be mentioned in the duty shift, all the participants pointed out: emergency cart, hemodialysis check and checkup, ten indicated: hospitalizations, discharges, diets, defective equipment and seven of the nurses indicated purge organization.

Regarding the duty shift modality, all the nurses indicated the option at the bedside, ten nurses indicated the written report, nine indicated the option of verbal transmission, four nurses indicated the option of associated duty shift methods, two nurses indicated devices electronics.

Regarding the time taken to perform duty shift, it was an open question, so six nurses described that the duty shift should occur between 10 and 15 minutes, two nurses described 15 to 20 minutes, another two of 20 to 30 minutes, a nurse described that the duty shift should occur without predetermined time, using the time needed to transmit all relevant information.

The factors that undermine duty shift, pointed out by nine of the participants, were interruptions by other professionals, followed by the external noises pointed out by six nurses. Other factors such as delay of colleagues, forgetfulness of information, lack of privacy, lack of interest, lack of method of registration, emergencies or intercurrences, had two notes each factor.

The seminar phase is the main stage of action research, since it allows the simultaneous occurrence of several other phases, such as: the theory stage, hypothesis, learning, problem placement, formal knowledge and informal knowledge. During the seminars, it is possible to examine, discuss and make decisions 
about the research process, to coordinate the activities of the group, to centralize all the information collected, to discuss the interpretations, to elaborate research guidelines and action guidelines submitted to the interested parties, which will be tested participants' practice ${ }^{(12)}$.

Five meetings were held, with a mean duration of 53 minutes, starting with an expositive lecture on aspects related to duty shift. The exhibition lasted on average ten minutes, the purpose was to update participants on the topic and enrich the discussions.

The discussions were intended to organize the duty shift in the unit, verify the applicability, make the necessary modifications to the adequacy of the registration tool and capture content to elaborate a SOP. The proposed topics were: place of information record on duty shifts, the most appropriate modality, the time required for the activity and the organization of the unit in duty shifts.

In the evaluation and adaptation of version 1 of the tool, the format and removal of items such as: "antibiotics, hemodialysis, blood transfusions and drains" were registered and recorded in other documents. The number of items was adjusted to fit three to five patient reports per page, so filling was faster. The justification for these changes was that the tool version 1 (checklist) was long and with an excess of components such as words, acronyms and symbols that left it time consuming and visually polluted.

The content learned during the meetings with the participants, which were used for the formulation of the SOP, is presented in Chart 1.

Version 2 of the tool was subjected to specialist validation. The participants of this phase were four specialists, three of them female. The mean age was 36 years, mean training time in the area was 13 years and all had specialization as higher titration.

Chart 1 - Content seized at meetings with participants

\begin{tabular}{|c|c|}
\hline $\begin{array}{l}\text { Theme } \\
\text { discussed }\end{array}$ & Content agreement \\
\hline $\begin{array}{l}\text { Information } \\
\text { record }\end{array}$ & $\begin{array}{l}\text { - Book of intercurrence: annotations on the work team, } \\
\text { presence of attestations, absences, delays and overtime; } \\
\text { equipment borrowed and defective; intercurrences with } \\
\text { other sectors; from any source. } \\
\text { - Duty shift registration tool: unique patient information. } \\
\text { - Information such as surgeries, procedures, scheduled } \\
\text { exams, fasting, isolation, contact precaution, airway or } \\
\text { droplets, allergies, mobilization restrictions, should be } \\
\text { recorded on the duty shift tool and on the plaques in the } \\
\text { patient's box. }\end{array}$ \\
\hline Modalities & $\begin{array}{l}\text { - Associated method between bedside duty shift } \\
\text { with verbally transmitted information and use of } \\
\text { registration tool. }\end{array}$ \\
\hline $\begin{array}{l}\text { Time spent on } \\
\text { the activity }\end{array}$ & $\begin{array}{l}\text { - The time set for the duration of the activity was } \\
\text { between ten and twenty minutes. }\end{array}$ \\
\hline $\begin{array}{l}\text { Unit } \\
\text { organization }\end{array}$ & $\begin{array}{l}\text { - In duty shifts, the nursing station, arsenal of } \\
\text { materials and purge must be organized. } \\
\text { - Enteral and parenteral diets installed and checked } \\
\text { with beginning and ending. } \\
\text { - Hemodialysis checked in the computer system. } \\
\text { - The emergency cart is checked and complete. } \\
\text { - Alarms of patient monitors with parameters } \\
\text { connected and adjusted. }\end{array}$ \\
\hline
\end{tabular}

In the validation process, the tool for duty shift was considered adequate (CVI: 1.0), regarding appearance, clarity, suitability for the sector and content, however, they had suggestions for improvement, which were analyzed and accepted when pertinent. Among the suggestions are: the reinsertion of the item "drain". $\mathrm{M}$ (morning), L (late) and $\mathrm{N}$ (night) were added to identify the periods of altered level of consciousness, ICP values, changes in glycaemia values and diuresis volume.

The items "VAD" and "sedation" were replaced by the item "medications". Changed item "flow", it was included after the "medications" item. Spaces were included after the items "ICP", "diuresis and evacuations" in order to allow the quantification and to identify changes in patients' clinical picture. The elaborated and validated duty shift information record is shown in Figure 2.

\section{DISCUSSION}

Duty shift is an activity that influences several dimensions of care. When analyzing the DCS presented in the results, the importance of the duty shift, considered by the participants as a means for care planning, continuity of care and for the organization of work, is evidenced. It is important to highlight that, in addition to these characteristics raised from DCS, the literature describes duty shift as a vehicle to promote patient safety through effective communication ${ }^{(16)}$.

Effective communication in duty shifts is facilitated when registration tools are used for information ${ }^{(17)}$. In the results of the exploratory phase, the written report was chosen as a preference modality by ten of the 11 nurses, as a result of this result, a registry tool with patient information was proposed, elaborated from the items selected by the participants.

The first proposal to the group was a checklist; however, participants opted for a more compact model. It is important to emphasize that contrary to the opinion of the participants, the literature considers the use of checklists during duty shift, a suitable tool for use in ICU and able to promote safe nursing practice ${ }^{(18)}$.

The use of checklists facilitates the clinical thinking and organization of patient information and can be adapted to critical units such as the ICU, taking into account the particularities of the patients hospitalized in these units and the technologies found in these units, as well as the magnitude of the decisions clinics that nurses are led to take through specialized and uninterrupted care $^{(10)}$. 
The items that composed the tool, described in the results, are in line with the recommendations of the World Health Organization (WHO), regarding the patient's clinical condition and intercurrences in the shift ${ }^{(2)}$. There was contradiction about some of the results obtained in the exploratory phase, with the questionnaire, compared to the ones obtained during the seminar phase, among which are some items that would come to comprise the tool such as "hemodialysis", "blood transfusion", "antibiotics" and "drains", these items were selected or described in the questionnaire, however, in the meetings the participants chose not to put this information in the registration tool.

Similarity occurred in another study that sought to identify factors related to patient safety regarding communication in the duty shift. The authors described that the professionals passed on information, such as the patient's clinical condition and intercurrences during the shift, however, they concluded that it is worrisome to refer less frequently to information related to medications, alteration in treatment and general care ${ }^{(19)}$.

After the adequacy of the registration tool, it was submitted to the validation by specialists. The suggestions provided by the participants of this phase provided improvements to the tool and allowed it to have its appearance and content validated for the intended reality.

The design of the duty shift was established by the elaboration of the SOP; this standardization model is used in the study institution by recommendation of the quality sector of the hospital and has the advantage of being an easy implementation tool. In the SOP, it was described the duty shift mode, the time spent to carry out the activity and the administrative and organizational information of the unit that must be transmitted in duty shifts.

The association between the modality "at the edge of the bed" and "the registration tool", was considered the most appropriate to the sector. It is important to highlight that the duty shift at the bedside promotes safety in health services, since it facilitates the participation of the user in their care, improvement of individual care, confidentiality and privacy of individuals, as well as incorporation of social aspects ${ }^{(20-21)}$.

The time for the duty shift in the unit was between ten to twenty minutes. It is believed to be sufficient for the transmission of all relevant information. The time spent on duty shift will determine the quantity, mode of transmission and quality of information. If it is very long, it leaves the activity exhausting and contributes to the dispersion of the team, if it is too short, the information will be passed quickly, facilitating the losses or misinterpretations, therefore, the time must adapt to the needs of each sector, number of team members and patient characteristics ${ }^{(7)}$.

As for the factors that negatively interfere with the duty shift, interruptions, external noises and lack of punctuality were highlighted, results corroborated by the literature, which also add other situations, such as the turmoil of people and the excess of parallel conversations in the workplace ${ }^{(19-22)}$.

In a study that measured the frequency and reason for interruptions during duty shifts in ICU, it was observed that parallel conversations among team members, nurses or physicians, and intravenous pump alarms are primarily responsible for interruptions, and that such situations may lead to loss of critical information and result in adverse events to patients ${ }^{(23)}$.

The administrative and organizational order information of the unit, with focus on duty shift, are peculiar aspects to each institution and sector, however, the literature presents these questions, emphasizing the managerial competencies of the nurse, such as leadership, communication, human resources management and materials ${ }^{(24)}$

In this study, competences in relation to people management, such as the presence of certificates, absences, delays, overtime and information related to material management, such as borrowed and defective equipment, other sectors and pendings of any origin.

The characteristics inherent to intensive care, such as the high number of interventions performed, the high risk decisions made by the multidisciplinary team, the variety of equipment and more complex drug arsenal, are situations that predispose patients to a greater risk of suffering adverse events ${ }^{(25)}$.

Adverse events are incidents with damage or impairment in the structure or functions of the organism, including injury, disability or death, but they can be used as indicators of quality, allowing the planning of a health system safer, if necessary, risk management, event notifications and focus on safety culture ${ }^{(26)}$.

The systematization of nursing work processes, as in this study, the standardization of duty shift is presented as a means to solve problems and risks related to the lack of communication and, consequently, to the reduction of adverse events.

\section{Study limitations}

One limitation of this study was the non-inclusion of nursing technicians, as well as the multiprofessional team, considering that these could extend the dimensions of the duty shift, allowing this activity, besides fulfilling its primary functions, is still an activity that adds and share knowledge among professionals, promoting transdisciplinarity.

\section{Contributions to the professional practice of Nursing}

The study presents a way to develop research, using the practice and experience of the participants. The patient information registration tool was validated for use in the ICU and can be used in other sectors or institutions, provided it is in the context of urgency and emergency.

The tools developed to standardize the duty shift demonstrate that the standardization of nursing activities and procedures contribute to the promotion of safe patient care and quality in health services.

\section{FINAL CONSIDERATIONS}

This research made possible the standardization of duty shift through the elaboration and validation of a tool for recording patient information and formulating a SOP to delineate the activity.

The tool assists in the transmission of information during duty shift, in order to ensure patient safety by standardizing this activity. If used correctly, these tools can improve the duty shift in the ICU, minimizing the risks of communicative process failures.

The elaboration of the tool and SOP occurred in the middle of the practice, because in this research, the intention was to enable participants to reflect on their reality, identify difficulties, problems and ponder possible solutions. The employed research-action method proved to be efficient, since it provided the development of a collaborative work between the researchers and the participants. 


\section{REFERENCES}

1. Machado EP, Haddad JGV, Zoboli ELCP. [Communication as light technology for humanizing nurse-patient relationship in Basic Assistance to Health]. Rev Bioéthikos [Internet]. 2010 [cited 2016 Apr 10]; 4(4):447-52. Available from: http://www.saocamilo-p.br/pdf/bioethikos/80/ Bioethikos_447-452_.pdf. Portuguese.

2. Communication during Patient Hand-overs. Patient Safety Solutions. Patient Saf Solution [Internet]. 2007 [cited 2016 Jul 10];1(3):1-4. Available from: http://www. who.int/patientsafety/solutions/patientsafety/PSSolution3.pdf

3. The Joint Commission. 2018 National Patient Safety Goals: 2018. [place unknow]: The Joint Commission; c2018 [cited 2018 Sep 09]. Available from: http://www.jointcommission.org

4. Neves ALD, Sanna MC. [Transformations of the communicative process models used in the nursing shift changes from 1974 to 2011 in Brazil]. Hist Enferm Rev Eletrônica. [Internet]. 2012 [cited 2016 Apr 15];3(1):56-75. Available from: http://www.here.abennacional.org.br/ here/vol3num1artigo5.pdf. Portuguese.

5. Portal KM, Magalhães AMM. Passagem de Plantão: um recurso estratégico para a continuidade do cuidado em enfermagem. Rev Gaúch. Enferm [Internet]. 2008 [cited 2016 Feb 20];29(2):246-53. Available from: http://seer.ufrgs.br/index.php/RevistaGauchadeEnfermagem/ article/view/5588/3198.

6. Penaforte MHO, Martins MMFPS. [The visibility of hygiene self-care in nurse-to-nurse shift change reports]. Rev Lat Am Enfermagem [Internet]. 2011 [cited 2016 Jun 12];19(1):1-9.Available from: http://dx.doi.org/10.1590/S0104-11692011000100018.English, Portuguese, Spanish.

7. Silva E, Campos LF. Passagem de plantão na enfermagem: revisão da literatura. Cogitare Enferm. [Internet]. 2007 [cited 2017 Sep 20];12(4):502-7. Available from: http://revistas.ufpr.br/cogitare/article/view/10077/6929. doi: http://dx.doi.org/10.5380/ce.v12i4.10077

8. Spooner AJ, Chaboyer W, Corley A, Hammond N, Fraser JF. Understanding current intensive care unit nursing handover practices. Int J Nurs Pract [Internet]. 2013 [cited 2016 Feb 15];19(2):214-20. Available from: http://onlinelibrary.wiley.com/doi/10.1111/ijn.12058/pdf.

9. Ministério da Saúde (BR), Agência Nacional de Vigilância Sanitária (ANVISA). Resolução n. 7, de 24 de fevereiro de 2010. Dispõe sobre os requisitos mínimos para funcionamento de Unidades de Terapia Intensiva e dá outras providências [Internet]. Diário Oficial da União: República Federativa do Brasil; 2010 [cited 2018 Sep 09].Feb 25, Seção 1: p. 48. [about 06 screens]. Available from:: http://bvsms.saude.gov. br/bvs/saudelegis/anvisa/2010/res0007_24_02_2010.html.

10. Ramalho Neto JM, Fontes WD, Nobrega MML. [Instrument to collect nursing data in General Intensive Care Unit]. Rev Bras Enferm [Internet]. 2013 [cited 2017 Jan 10];66(4):535-42. Available from: http://dx.doi.org/10.1590/S0034-71672013000400011. Portuguese.

11. Chaves L D P, Laus A M, Camelo S H. Ações gerenciais e assistenciais do enfermeiro em unidade de terapia intensiva. Rev. Eletr Enf [Internet]. 2012 [cited 2016 Aug 16];14(3):671-8. Available from: https://doi.org/10.5216/ree.v14i3.15724

12. Thiollent M. Metodologia da Pesquisa Ação. 18 ed. São Paulo: Cortez, 2011. 136 p.

13. Lefebvre F, Lefebvre AMC. O discurso do sujeito coletivo: um novo enfoque em pesquisa qualitativa Caxias do Sul: EDUCS, 2003. 256 p.

14. Hasson F, Keeney S. Enhancing rigour in the Delphi technique research. Technol Forecast Soc Change [Internet]. 2011 [cited 2016 Dec 10];78(9):1695-704. Available from: https://doi.org/10.1016/j.techfore.2011.04.005

15. Alexandre NM, Coluci MZO. [Content validity in the developmentand adaptation processes of measurement instruments]. Ciênc Saúde Colet [Internet]. 2011 [cited 2017 Feb 20];16(7):3061-3068. Available from: http://dx.doi.org/10.1590/S1413-81232011000800006. Portuguese.

16. Silva SG, Nascimento ERP, Hermida PMV, Sena AC, Klein TCR, Pinho FM. Checklist para passagem de plantão de pacientes em pós-operatório imediato na Admissão em terapia intensiva. Enferm Foco [Internet]. 2016 [cited 2016 Nov 24];7(1):13-7. Available from: http://revista. portalcofen.gov.br/index.php/enfermagem/article/view/658/277

17. Sousa CS, Souza RCS, Gonçalves MC, Diniz TRZ. Comunicação efetiva entre centro cirúrgico e Unidade de Terapia Intensiva. Rev SOBECC [Internet]. 2014 [cited 2016 Dec 10];19(1):44-5. Available from: http://doi.editoracubo.com.br/10.4322/sobecc.2014.004

18. Malekzadeh J. A standardized shift handover protocol: Improving Nurses' Safe Practice in Intensive Care Units. J Caring Sci [Internet]. 2013 [cited 2016 Feb 15];2(3):177-85. Available from: http://www.ncbi.nlm.nih.gov/pmc/articles/PMC4134157/

19. Gonçalves MI, Rocha PK, Anders JC, Kusahara DM, Tomazoni A. Communication and patient safety in the change-of-shift nurssing report in neinatal intensive care units. Texto Contexto-Enferm [Internet]. 2016 [cited 2016 Nov 08];25(1):e2310014 Available from: http://dx.doi. org/10.1590/0104-07072016002310014. English, Portuguese.

20. Kerr D, Lu S, McKinlay L. Towards patient-centred care: Perspectives of nurses and midwives regarding shift-to-shift bedside handover. Int J Nurs Pract [Internet]. 2014 [cited 2016 Feb 15];20(3):250-7. Available from: http://onlinelibrary.wiley.com/doi/10.1111/ijn.12138/pdf

21. Bradley S, Mott S. Adopting a patient-centred approach: an investigation into the introduction of bedside handover to three rural hospitals. J Clin Nurs [Internet]. 2013 [cited 2016 Feb 12];23(13-14):1927-36. Available from: http://onlinelibrary.wiley.com/doi/10.1111/jocn.12403/pdfS

22. Rodriguez L, Oliveira EO, França CS, Andrade TR, Campos JS, Silva MP, Costacurta FJ. Mapeamento da passagem de plantão sob a ótica dos profissionais de enfermagem. Enferm Glob [Internet]. 2013 [cited 2016 Feb 21];(31):219-31. Available from: http://scielo.isciii.es/pdf/eg/ 
v12n31/pt_administracion4.pdf

23. Spooner AJ, Corley A, Chaboyer W, Hammond NE, Fraser JF. Measurement of the frequency and source of interruptions occurring during bedside nursing handover in the intensive care unit: An observational study. Aust Crit Care [Internet]. 2015 [cited 2016 Feb 16];28(1):19-23. Available from: http://www.australiancriticalcare.com/article/S1036-7314(14)00031-9/fulltext

24. Deckman LR, Deon SMP, Silva EF, Lorenzini E. Competência gerencial na enfermagem: uma revisão integrativa. Rev Eletrônica Gest Saúde [Internet]. 2013 [cited 2017 Jun 10];4(2):2261-72. Available from: http://dx.doi.org/10.18673/gs.v4i2.22952

25. Novaretti MC, Santos EV, Quitério LM, Daud-Gallotti RM. [Nursing workload and occurrence of incidents and adverse events in ICU patients]. Rev Bras Enferm [Internet]. 2014 [cited 2016 Nov 24];67(5):692-9. Available from: http://dx.doi.org/10.1590/0034-7167.2014670504. Portuguese.

26. Vlayen A. Design of a medical record review study on the incidence and preventability of adverse events requiring a higher level of care in Belgian hospitals. BMC Res Notes [Internet]. 2012 [cited 2017 Feb 10];5:468. Available from: https://www.ncbi.nlm.nih.gov/pmc/articles/ PMC3542154/ 